\title{
PEMAHAMAN KONSEP MATEMATIKA SISWA KELAS V SD NEGERI RAU KEDUNG JEPARA PADA MATERI PERKALIAN PECAHAN
}

\author{
Nor Aulia Mukrimatin ${ }^{1 \bowtie}$, Murtono $^{2}$, dan Savitri Wanabuliandari ${ }^{3}$ \\ ${ }^{1,2}$ Prodi Pendidikan Guru Sekolah Dasar, Universitas Muria Kudus \\ ${ }^{3}$ Prodi Pendidikan Matematika, Universitas Muria Kudus
}

\section{Info Artikel}

Sejarah Artikel: Diterima 24 Feb 2018 Direvisi 20 Mar 2018

Disetujui 20 Apr 2018

Keywords: Mathematic Concept Comprehension, Guided Discovery Learning Model, Kaki Bima Game

\section{Paper type:}

Research paper

\section{Abstract}

The purpose of this research is 1) to know the result of the interview with the teacher related to the understanding of methematics concept, 2) to know the result of the observation of learning related to the understanding of methematics concept, 3) to know the result of the initial test of the students related to the understanding of mathematichal concepts. The location of study is SD Negeri Rau Kedung Jepara Jawa Tengah Indonesia. The study was conducted in the even semester of May of 2018. The subjects of this study were V graders and V graders of State Elementary School which amounted to 22 students. Data collection techniques using interviews with observation teachers and tests. After obtaining data is done with kuantitative data analysis techniques and kualitative data analysis techniques. Based on interviews, observation and pretest is known that understanding of student concept is still low.

\section{Abstrak}

Tujuan penelitian ini adalah (1) mengetahui hasil wawancara dengan guru terkait pemahaman konsep matematika, (2) mengetahui hasil observasi pembelajaran terkait pemahaman konsep matematika, (3) mengetahui hasil tes awal peserta didik terkait pemahaman konsep matematika. Lokasi penelitian ini adalah SD Negeri Rau Kedung Jepara Jawa tengah Indonesia. Penelitian dilaksanakan pada semester genap bulan mei tahun 2018. Subjek penelitian ini adalah guru kelas V dan peserta didik kelas V SD Negeri Rau yang berjumlah 22 peserta didik. Teknik pengumpulan data menggunakan wawancara dengan guru, observasi, dan tes. Setelah mendapatkan data, dilakukan dengan teknik analisis data kuantitatif deskriptif dan teknik analisis data kualitatif. Berdasarkan hasil wawancara, observasi dan pretest diketahui bahwa pemahaman konsep siswa masih rendah

(C) 2018 Universitas Muria Kudus

\footnotetext{
Alamat korespondensi:

Program Studi Pendidikan Matematika, Universitas Muria Kudus

Kampus UMK Gondangmanis, Bae Kudus Gd. L lantai 1 Ruang 2 PO BOX 53 Kudus

Tlp. (0291) 438229 Fax. (0291) 437198

Email: aulioaulia@gmail.com
} 


\section{PENDAHULUAN}

Pendidikan memiliki peranan yang sangat penting dalam proses peningkatan kualitas sumber daya manusia. Oleh karena itu sudah sepatutnya pendidikan mendapat perhatian yang mendalam tentang nilai-nilai dan dasar-dasar untuk meningkatkan kualitas sumber daya manusia. Salah satu cara meningkatkan kualitas sumber daya manusia yakni dengan memperbaiki kualitas pembelajaran di sekolah. Matematika merupakan salah satu mata pelajaran yang memegang peranan sangat penting dalam pendidikan. Hal ini sejalan dengan pendapat Susanto (2013:183) yang menyatakan bahwa dengan belajar matematika, kita akan belajar bernalar kritis, kreatif, dan aktif yang sangat dibutuhkan orang dalam menyelesaikan berbagai masalah. Sebagaimana diketahui bahwa salah satu tujuan mata pelajaran matematika dijelaskan dalam Peraturan Menteri Pendidikan Nasional (Permendiknas) Nomor 22 Tahun 2006 tentang Standar Isi Mata Pelajaran Matematika untuk semua jenjang pendidikan dasar dan menengah adalah agar peserta didik memiliki kemampuan memahami konsep matematika, menjelaskan keterkaitan antarkonsep dan mengaplikasikan konsep atau algoritma, secara luwes, akurat, efisien dan tepat dalam pemecahan masalah. Mengingat pentingnya proses pembelajaran matematika, seluruh aspek pendidikan memberikan evaluasi terhadap pembelajaran matematika.

Setyabukti (dalam Handayani, 2015: 144) mengemukakan bahwa pembelajaran matematika di Indonesia memang masih menekankan menghapal rumus-rumus dan menghitung, hal tersebut yang menyebabkan kemampuan pemahaman peserta didik kurang berkembang. Kurangnya kemampuan pemahaman konsep di Indonesia diindikasikan bahwa terjadi permasalahan pada saat proses pembelajaran matematika. Berdasarkan observasi awal di SD Negeri Rau Kedung Jepara terdapat permasalahan, yakni peserta didik kurang menguasai indikator pemahaman konsep matematika. Selain itu guru kurang menggunakan media dalam pembelajaran. Indikator pemahaman konsep matematika menurut Zuliana (2017:2) yaitu (1) menyatakan ulang sebuah konsep, (2) mengklasifikasikan objek-objek menurut sifat-sifat tertentu (sesuai dengan konsepnya), (3) memberikan contoh dan noncontoh dari konsep, (4) menyajikan konsep dalam berbagai bentuk representasi matematika, (5) mengembangkan syarat perlu atau syarat cukup suatu konsep, (6) menggunakan, memanfaatkan, dan memilih prosedur atau operasi tertentu, (7) mengaplikasikan konsep atau algoritma pemecahan masalah. Sedangkan Menurut Eggen dan Kauchak (dalam Mawaddah dan Maryanti) pengetahuan siswa dan pemahamannya tentang suatu konsep bisa diukur melalui empat cara, yakni dengan meminta mereka untuk: (1) mendefinisikan konsep; (2) mengidentifikasi karakteristik-karakeristik konsep; (3) menghubungkan konsep dengan konsep-konsep lain; (4) mengidentifikasi atau memberikan contoh dari konsep yang belum pernah dijumpai sebelumnya. Hal ini berarti bahwa permasalahan di SD Negeri Rau Kedung Jepara harus segera diatasi karena pada dasarnya pemahaman konsep penting bagi peserta didik.. Pada dasarnya penanaman konsep peserta didik memerlukan alokasi waktu yang cukup lama, apalagi menanamkan konsep kepada peserta didik Sekolah Dasar yang belum mampu berpikir secara abstrak.

Salah satu cara upaya peningkatan pemahaman konsep adalah melalui variasi model pembelajaran. Model pembelajaran $R M E$ terpilih sebagai solusi yang tepat karena memberikan pendekatan pembelajaran menggunakan hal-hal yang nyata dan pengalaman peserta didik sebagai titik awal belajar matematika. Fathurrohman (2015:189) mengatakan bahwa model yang dapat digunakan adalah model $R M E$, model Realistics Mathematics Education merupakan suatu pendekatan mpembelajaran matematika yang menggunakan situasi dunia nyata atau suatu konsep yang real dan pengalaman siswa sebagai titik tolak belajar matematika. Pendapat tersebut bertentangan dengan Wijaya (2011:20-21) permasalahan realistik tidak harus selalu berupa masalah yang ada di dunia nyata (real world problem) dan bisa ditemukan dalam kehidupan sehari-hari. jadi, suatu masalah disebut "realistik" jika masalah tersebut dapat dibayangkan (real) dalam pikiran peserta didik. Dari uraian tersebut dapat disimpulkan bahwa pembelajaran realistik adalah pembelajaran yang dapat dibayangkan dalam pikiran peserta didik seolah-olah nyata yang mampu membentuk pengetahuan peserta didik antara pengalaman yang telah diperoleh dan penerapannya dalam kehidupan sehari-hari. Meskipun demikian, model pembelajaran $R M E$ mempunyai beberapa kelemahan, salah satunya yakni membutuhkan waktu yang lama untuk peserta didik menentukan jawabannya sendiri. Namun kelemahan tersebut dapat diminimalisir dengan bantuan penggunaan media alat peraga berupa Folding Paper (kertas lipat).

Folding Paper ini merupakan alat peraga yang sesuai dengan pembelajaran matematika materi pecahan khususnya mengalikan pecahan dengan pecahan dan perkalian pecahan dengan 
bilangan asli. Penggunaan alat peraga Folding Paper ini membantu peserta didik untuk menemukan konsep sendiri mengenai materi tersebut. Sependapat dengan penelitian Akhsa (2017:11) bahwa pemberian pembelajaran materi penjumlahan pecahan dengan bantuan media alat peraga kertas lipat, dapat meningkatkan hasil belajar peserta didik. Penelitian tersebut membuktikan bahwa penggunaan alat peraga Folding Paper (kertas lipat) pada materi pecahan dapat meningkatkan pembelajaran matematika dengan cara yang menyenangkan. Wanabuliandari (2016:35) mengungkapkan bahwa pembelajaran yang menyenangkan akan berdampak pada peningkatan prestasi belajar peserta didik karena (1) membuat peserta didik gembira dan pembelajaran terasa lebih mudah, (2) adanya komunikasi yang efektif dan penuh keakraban. Dengan pembelajaran yang menyenangkan diharapkan peserta didik mampu menerima pembelajaran matematika tanpa ada pemikiriran bahwa matematika itu sulit dan susah dikerjakan.

Tujuan dalam penelitian ini adalah (1) mengetahui hasil wawancara dengan guru terkait pemahaman konsep matematika, (2) mengetahui hasil observasi pembelajaran terkait pemahaman konsep matematika, (3) mengetahui hasil tes awal peserta didik terkait pemahaman konsep matematika.

\section{METODE PENELITIAN}

Lokasi penelitian ini adalah SD Negeri Rau Kedung Jepara Jawa tengah Indonesia. Penelitian dilaksanakan pada semester genap bulan mei tahun 2018. Subjek penelitian ini adalah guru kelas V dan peserta didik kelas V SD Negeri Rau yang berjumlah 22 peserta didik. Sugiyono (2013, 38) Variabel penelitian merupakan segala hal yang telah ditetapkan oleh peneliti untuk diteliti agar dapat memperoleh informasi dan ditarik kesimpulan. Variabel yang digunakan dalam penelitian dibagi menjadi variabel bebas yang menjelaskan dan mempengaruhi variabel lain, dan variabel terikatl yang dijelaskan dan dipengaruhi oleh variabel bebas. Variabel bebas yang digunakan dalam penelitian adalah media Folding Paper dan model RME. Folding Paper ini merupakan alat peraga yang sesuai dengan pembelajaran matematika materi pecahan khususnya mengalikan pecahan dengan pecahan dan perkalian pecahan dengan bilangan asli. Fathurrohman (2015:189) mengatakan bahwa model yang dapat digunakan adalah model $R M E$, model Realistics Mathematics Education merupakan suatu pendekatan mpembelajaran matematika yang menggunakan situasi dunia nyata atau suatu konsep yang real dan pengalaman siswa sebagai titik tolak belajar matematika. Variabel terikat dalam penelitian ini yakni pemahaman konsep matematika peserta didik. Teknik pengumpulan data menggunakan wawancara dengan guru kelas $\mathrm{V}$, observasi, dan tes. Instrument yang digunakan adalah lembar wawancara, lembar observasi, dan tes pemahaman konsep. Setelah mendapatkan data, dilakukan dengan teknik analisis data kuantitatif deskriptif dan teknik analisis data kualitatif.

\section{HASIL DAN PEMBAHASAN}

Penelitian dilaksanakan di SD Negeri Rau. Data diperoleh dengan menggunakan instrument wawancara terhadap peserta didik dan guru, observasi pembelajaran di kelas $\mathrm{V}$ dan tes awal. Pengisian lembar wawancara, peserta didik dan guru diberikan pertanyaan dengan wawancara terstruktur yang berisi tentang indikator pemahaman konsep matematika, observasi terhadap pembelajaran dan tes awal untuk mendeskripsikan pemahaman konsep matematika peserta didik yang berkaitan dengan pecahan.

Berdasarkan hasil wawancara yang dilaksanakan, peneliti menemukan permasalahan dalam pembelajaran matematika banyak peserta didik yang belum menguasai indikator pemahaman konsep. Sebagian peserta didik sudah mampu menyatakan ulang sebuah konsep, peserta didik masih kebingungan untuk mengenali objek berdasarkan sifatnya, peserta didik dengan bantuan guru mampu membedakan contoh dan bukan contoh, peserta didik kesulitan mengartikan soal terutama soal yang berbentuk cerita dan tidak mampu memodelkan pernyataan ke dalam bentuk matematika. Hal ini sejalan dengan pendapat Dharma, Suarjana dan Suartama (2016:3) yang menyatakan bahwa ternyata masih banyak terdapat siswa yang mengalami kesulitan dalam menyelesaikan soal matematika dalam bentuk cerita, memahami bahasa, apa yang ditanyakan dalam soal, dan dalam perhitungan.

Berdasarkan wawancara dengan guru, peserta didik tidak bisa mengembangkan syarat yang diperlukan karena masih terpaku dengan hapalan rumus, peserta didik hanya meniru penyelesaian soal yang sama dengan guru, ketika diberikan soal yang berbeda, ia masih bingung bagaimana cara penyelesaiannya, peserta didik banyak yang salah dalam perhitungan sehingga jawaban tidak tepat. Hasil wawancara tersebut, menunjukkan bahwa peserta didik kurang menguasai pemahaman terhadap konsep matematika. Padahal, penguasaan pemahaman konsep tentang materi menunjukkan siswa 
tersebut mampu untuk mempelajari konsep selanjutnya. Hal ini sejalan dengan Susanto (2013:209) yang menyatakan bahwa pemahaman dan penguasaan suatu materi atau konsep merupakan prasyarat untuk menguasai materi atau konsep selanjutnya.

Hasil observasi aktivitas peserta didik, diperoleh gambaran bahwa secara umum peserta didik kurang minat dalam pembelajaran matematika, respon peserta didik terhadap pembelajaran kurang, hanya beberapa peserta didik yang mampu mengikuti pembelajaran, selain itu peserta didik masih kesulitan mengartikan soal yang berbentuk cerita, ia masih kebingungan bagaimana cara untuk menyelesaikan, karena peserta didik tidak memahami apa yang diketahui dan apa yang ditanya dari soal. Ketika diberikan soal yang berbeda ia terpaku pada cara penyelesaian soal yang diberikan guru, sehingga ia tidak menemukan jawabannya dan peserta didik tidak teliti dalam melakukan perhitungan. Hasil tersebut membuktikan bahwa pemahaman konsep terhadap pembelajaran matematika di SD Negeri Rau perlu ditingkatkan, karena dengan pemahaman konsep peserta didik mampu untuk menyelesaikan berbagai permasalahan dalam matematika. Hal ini senada dengan Purwasih (2015:17) mengemukakan bahwa kemampuan pemahaman matematika mampu membantu siswa senantiasa berpikir secara sistematis dan mampu menyelesaikan masalah matematika dalam kehidupan sehari-hari serta mampu menerapkan matematika dalam berbagai bidang ilmu pengetahuan lain.

Hasil tes awal yang dilaksanakan oleh peneliti pada peserta didik kelas V SD Negeri Rau Kedung Jepara Tahun Pelajaran 2017/2018 dengan soal yang berbentuk uraian berjumlah tujuh pada materi pecahan ditunjukkan hasil tes kemampuan pemahaman konsep peserta didik masih kurang, nilai hasil tes awal masih banyak yang belum memenuhi Kriteria Ketuntasan Minimal (KKM). KKM di kelas V SD Negeri Rau adalah 60. Terdapat 3 peserta didik dari jumlah seluruh 22 peserta didik, yang nilainya memenuhi KKM dengan presentase 13,6\%. Hasil tes awal pemahaman konsep peserta didik disajikan dalam Tabel 1 berikut ini.
Tabel 1. Hasil Tes Pemahaman Konsep

\begin{tabular}{|c|c|c|}
\hline No & Pernyataan & Hasil \\
\hline 1. & $\begin{array}{l}\text { Menyatakan ulang sebuah } \\
\text { konsep }\end{array}$ & $50 \%$ \\
\hline 2. & $\begin{array}{l}\text { Mengklasifikasikan objek } \\
\text { menurut sifat sesuai dengan } \\
\text { konsepnya }\end{array}$ & $27,27 \%$ \\
\hline 3. & $\begin{array}{l}\text { Memberikan contoh dan non- } \\
\text { contoh }\end{array}$ & $30,68 \%$ \\
\hline 4. & $\begin{array}{l}\text { Menyajikan konsep dalam } \\
\text { berbagai bentuk representasi } \\
\text { matematika }\end{array}$ & $36,36 \%$ \\
\hline 5. & $\begin{array}{l}\text { Mengembangkan syarat perlu } \\
\text { atau syarat cukup suatu } \\
\text { konsep }\end{array}$ & $37,5 \%$ \\
\hline 6. & $\begin{array}{l}\text { Menggunakan, } \\
\text { memanfaatkan dan memilih } \\
\text { prosedur tertentu }\end{array}$ & $29,55 \%$ \\
\hline 7. & $\begin{array}{l}\text { Mengaplikasikan konsep atau } \\
\text { algoritma dalam pemecahan } \\
\text { masalah }\end{array}$ & $20,45 \%$ \\
\hline
\end{tabular}

Berdasarkan Tabel 1 dapat diketahui bahwa peserta didik mampu menyatakan ulang sebuah konsep dalam kategori sedang sebesar $50 \%$, peserta didik mampu mengklasifikasikan objek menurut sifat sesuai dengan konsepnya dalam kategori rendah yakni sebesar 27,27\%, peserta didik mampu memberikan contoh dan non-contoh dalam kategori rendah sebesar $30,68 \%$, peserta didik mampu menyajikan konsep dalam berbagai bentuk representasi matematika dalam kategori rendah sebesar $36,36 \%$, peserta didik mampu mengembangkan syarat perlu atau syarat cukup suatu konsep dalam kategori rendah sebesar 37,5\%, peserta didik mampu menggunakan, memanfaatkan dan memilih prosedur tertentu dalam kategori rendah sebesar 29,55\%, peserta didik mampu mengaplikasikan konsep atau algoritma dalam pemecahan masalah dalam kategori rendah sebesar 20,45\%. Skor rata-rata yang diperoleh pada pemahaman konsep hanya 33,11\%. Hasil tes awal tersebut menunjukkan lebih banyak peserta didik yang belum menguasai indikator pemahaman konsep, sehingga peneliti menyimpulkan bahwa peserta didik di SD Negeri Rau masih memiliki kemampuan pemahaman konsep yang kurang dalam materi pecahan. sependapat dengan penelitian Santi, Jenny dan Djaelani (2016) bahwa mengenai kemampuan menghitung pecahan, fakta yang ditemukan adalah Masih rendahnya pemahaman konsep pecahan yang dimiliki siswa dan sedikitnya siswa yang mampu melakukan operasi hitung pecahan.

\section{SIMPULAN}

Dari hasil wawancara dengan guru dapat ditarik kesimpulan bahwa hanya indikator menyatakan ulang sebuah konsep sudah dikuasai oleh peserta didik. Berdasarkan hasil observasi 
menunjukkan bahwa secara umum peserta didik kurang minat dalam pembelajaran matematika, respon terhadap pembelajaran kurang dan hanya beberapa yang mampu mengikuti pembelajaran. Berdasarkan hasil tes awal membuktikan bahwa kemampuan pemahaman konsep matematika peserta didik di SD Negeri Rau kedung Jepara masih rendah. Kontribusi bagi guru adalah memberikan pengetahuan kepada guru cara menganalisis pemahaman konsep peserta didik.

\section{UCAPAN TERIMAKASIH}

Penulis mengucapkan terimakasih kepada SD Negeri Rau Kecamatan Kedung Kabupaten Jepara yang telah memberikan ijin untuk melaksanakan kegiatan penelitian.

\section{DAFTAR PUSTAKA}

Aksha, M., dan Shaleh. 2017. Peningkatan Peserta Didik Dalam Memahami Konsep Penjumlahan Pecahan Dengan Menggunakan Alat Peraga Kertas Lipat. Lentera, 1(2): 9-12.

Dharma, I.M.A., Suarjana, I.M., dan Suartama, I.K. 2016. Analisis Kemampuan Menyelesaikan Soal Cerita pada Siswa Kelas IV Tahun Pelajaran 2015/2016 Di SD Negeri 1 Banjar Bali. e-Journal PGSD Universitas Pendidikan Ganesha, 4(1): 1-10.

Fathurrohman, Muhammad. 2015. Model-Model Pembelajaran Inovatif. Jogjakarta: ArRuzz Media

Handayani, H. 2015. Pengaruh Pembelajaran Kontekstual Terhadap Kemampuan Pemahaman dan Representasi Matematika Siswa Sekolah Dasar. Jurnal Pendidikan Guru Sekolah Dasar, 1(1): 142-149.

Mawaddah, S dan Ratih M. 2016. Kemampuan Pemahaman Konsep Matematika Siswa SMP dalam Pembelajaran Menggunakan Model Penemuan Terbimbing (Discovery Learning). EDU-MAT Jurnal Pendidikan Matematika, 4(1): 76 - 85.

Peraturan Menteri Pendidikan Nasional Republik Indonesia Nomor 22. 2006. Peraturan Menteri Pendidikan Nasional Republik Indonesia Nomor 22 Tahun 2006. Presiden Republik Indonesia.

Purwasih, R. 2015. Peningkatan Kemampuan Pemahaman Matematis dan Self Confidence Peserta didik Mts Di Kota Cimahi Melalui Model Pembelajaran Inkuiri Terbimbing. Didaktik, 9(1):16-25.

Santi, E.W, Jenny Is Poerwanti, dan Djaelani. 2016. Model Pembelajaran Kooperatif Tipe Think Pair Share untuk Meningkatkan Kemampuan Menghitung
Pecahan. Jurnal Didaktika Dwija Indria, 1-6.

Susanto, A. 2013. Teori Belajar dan Pembelajaran di Sekolah Dasar. Jakarta: Kencana.

Sugiyono. 2013. Metode Penelitian Pendidikan Pendekatan Kuantitatif, Kualitatif, dan $R \& D$. Bandung: Alfabeta.

Wanabuliandari, S, Sekar, D.A, dan Susilo R. 2016. Implementasi Model EJAS Berbasis Mathematic Edutainment Untuk Meningkatkan Prestasi Belajar dan Perilaku Kepedulian Terhadap Lingkungan. EduMa, 5(2): 34-41.

Wijaya, A. 2011. Pendidikan Matematika Realistik Suatu Alternatif Pendekatan Pembelajaran Matematika. Yogyakarta: Graha Ilmu.

Zuliana, E. 2017. Penerapan Inquiry Based Learning berbantuan Peraga Manipulatif dalam Meningkatkan Pemahaman Konsep Matematika pada Materi Geometri Mahasiswa PGSD Universitas Muria Kudus. Jurnal Pendidikan, 8(1): 35-43. 